症例

著明な負血，血小板減少を来した脾原発血管肉腫の 1 例

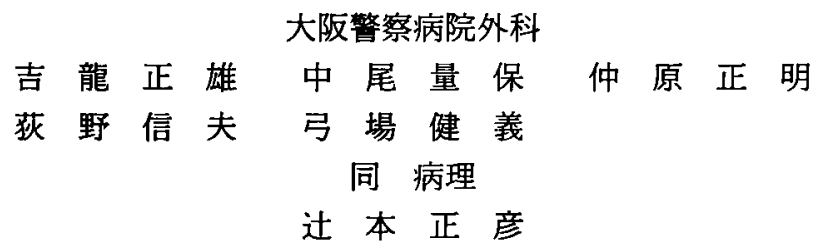

われわれは稀な脾原発血管肉腫の 1 手術例を経験した。症例は 45 歳, 女性. 主訴は筫 血と肝脾腫. 血液検查上著明な貧血, DIC および肝機能異常を認めた。腹部 CT, 超音波 検查にて, 肝脾に腫瘍性病変を認め, 血管造影, 肝針生検にて血管原性の腫瘍が示唆さ れた. 赤血球 $90 \times 10^{4} / \mathrm{mm}^{3}$ ，血小板 $1.2 \times 10^{4} / \mathrm{mm}^{3}$ と貧血, DIC が著しく進行するため脾 臓摘出術（摘出重量 $1,540 \mathrm{~g}$ ）を施行. 腫場細胞は CD31および第V四因子関連抗原に陽性で 脾原発血管肉腫と診断した. 術後, 肝動注化学療法(FAM), Interleukin-2の全身投与を 試みるも肝不全にて死亡した。脾原発血管肉腫の本邦報告例は21例のみて，12例に摘脾 術が施行され 6 力月以上生存は 1 例のみであった. 本症は早期診断が困難で予後不良の ため, 脾腫の鑑別診断の際には本症を念頭に置くべきと思われた。

索引用語：血管肉腫, 脾腫瘍, 脾蔵摘出術

\section{緒 言}

脾原発の血管肉腫は極めて稀な疾患で早期診断が困 難なうえに急速に增大転移し，極めて予後不良である. 今回, われわれは著明な肝脾腫, 䆭血, 血小板减少を 来した脾原発血管肉腫に対し，摘脾術を施行するも肝 転移巣の増大による肝不全にて死亡した 1 例を経験し た. 本症例の画像診断については既に報告”したので, 電灝組織所見を提示するとともに，本邦報告例を集計 し, 治療法や予後について考察した.

$$
\text { 症例 }
$$

患者：45歳, 女性.

主訴：右季肋部痛および右背部痛.

家族歴：特記すべきことなし.

既往歴：15歳時賓血を指摘された。17歳時, 虫垂炎 にて虫垂切除術. 40歳時, 子宮筋腫にて手術. なお， トロトラスト，塩化ビニルとの接触歴はない．

現病歴：平成 5 年11月頃，右季肋部痛および右背部 痛を自覚. 近医にて血小板減少, 脾腫を指摘され，某 院に入院. 諸検查の結果 Banti 症候群が疑われ, 平成 6 年 2 月 28 日当科紹介入院.

1997年 8 月29日受付 1997 年12月 1 日採用
入院時現症：身長 $156 \mathrm{~cm}$, 体重53kg. 4 カ月で $6 \mathrm{~kg} の$ 体重減少を認めた。眼球結膜に黄染, 眼瞼結膜に筫血 を認めた. 右季肋部に肝を $3 \mathrm{~cm}$, 左季助部に脾を $8 \mathrm{~cm}$ 触 知した。体表リンバ節を触知しなかった。

血液検查所見（表 1)：高度の貧血，血小板減少を示 し, 塗抹標本にて赤血球の大小不同, ジョリー小体, 多染性赤血球を認めた。また，肝機能異常および止血 能の低下を認め, 厚生省の診断基準により DIC と診断 した。

腹部超音波所見：肝脾ともに著明に腫大し，内部に 径 $5 \mathrm{~mm} \sim 10 \mathrm{~mm}$ 大の淡い low echoic lesion が散在し ていた，腹水を中等量認めた。

腹部 CT 所見 : 著明な肝脾腫を認め, volumetry に

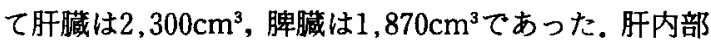
には結節性，脾内部には濔漫性に low density area を 認めた。リンパ節腫大は認められなかった（図1).

腹部血管造影所見：脾動脈の分枝は散開し，末梢に 微細血管の増生と斑状の staining が多発し, 血管原性 腫瘍による脾腫が疑われた。肝内に腫瘍濃染を認めな かったが, staining が不均一で転移を否定できない像 であった。

針生検肝組織所見：比較的異型性の乏しい小型腫瘍 
表 1 入院時血液検査所見

\begin{tabular}{lc}
\hline WBC & $19,300 / \mathrm{mm}^{3}$ \\
RBC & $181 \times 10^{4} / \mathrm{mm}^{3}$ \\
$\mathrm{Hb}$ & $6.8 \mathrm{~g} / \mathrm{dl}$ \\
$\mathrm{Hct}$. & $21.1 \%$ \\
Plt. & $3.3 \times 10^{4} / \mathrm{mm}^{3}$ \\
CRP & $8.7 \mathrm{mg} / \mathrm{dl}$ \\
T.P & $4.6 \mathrm{~g} / \mathrm{dl}$ \\
T. Bil & $1.4 \mathrm{~g} / \mathrm{dl}$ \\
D. Bil & $0.7 \mathrm{~g} / \mathrm{dl}$ \\
GOT & $93 \mathrm{IU} / l$ \\
GPT & $63 \mathrm{IU} / l$ \\
LDH & $1,664 \mathrm{IU} / l$ \\
Cre & $0.6 \mathrm{mg} / \mathrm{dl}$ \\
BUN & $13.0 \mathrm{mg} / \mathrm{dl}$ \\
PT.活性\% & $45.5 \%$ \\
PT 比 & 1.270 \\
APTT & $52.5 \mathrm{see}$ \\
Fibrinogen & $96.7 \mathrm{mg} / \mathrm{dl}$ \\
FDP & $14.5 \mu \mathrm{g} / \mathrm{dl}$ \\
直接 Coombs' test & $(-)$ \\
\hline
\end{tabular}

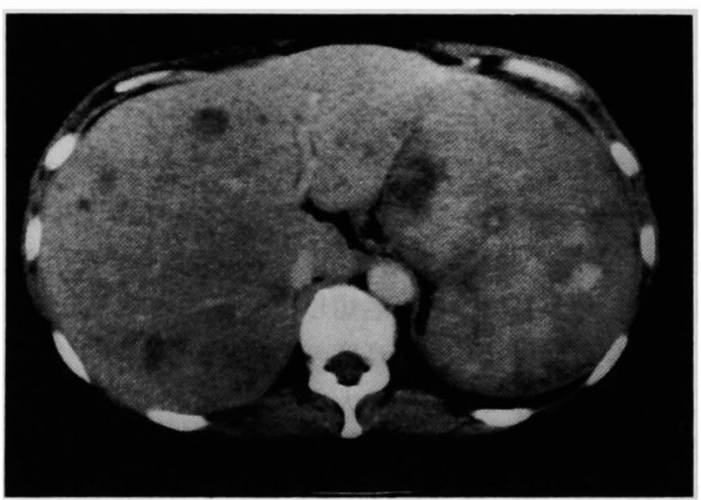

図 1 腹部造影 CT 検查：肝臓，脾臟は不均一に造影 された。脾臓は礵漫性に低吸収域を認め, 一部は著 明に造影された。

細胞が，血管腔様構造ないし乳頭状構造を形成して増 殖し,核分裂像は認められなかった。腫瘍細胞は CD31 および第VW因子関連抗原に陽性であり，上皮様血管内 皮腫と考えられた。

入院後, 負血, DIC, 肝脾腫は更に増悪し, 血小板は 入院時 $3.3 \times 10^{4} / \mathrm{mm}^{3}$ であったのが1.2×104/ $\mathrm{mm}^{3}$ にま で低下したため, 平成 6 年 3 月 22 日手術を施行した。

手術所見 : 上腹部正中切開に左第 7 肋間開胸を加え た。淡茶色，嶈液性の腹水を中等量認めた。肝脾とも に腫大し辺縁鈍，表面不整，斑状に変色し，軟らかい
腫溜を濔漫性に触知した，肝脾の間の強固な㾤着を剝 離し, 脾臓摘出術を施行した。

摘出標本：脾臟は大きさ $22 \times 13 \times 7.0 \mathrm{~cm}$, 重量 1,540 $\mathrm{g}$ であり, 割面はスポンジ状を呈し古い梗塞巣を認め た.

脾炡病理組織所見：N/C 比大で核小体の目立つ多 陵形の腫瑒細胞が，大小の血管腔様構造を形成して増 殖し，一部では充実性に増殖していた。 また紡錘形あ るいは異型性の多核巨細胞の形成も認められ，核分裂 像を多数認めた (図 2). 免疫組織染色では腫瘍細胞は CD31および第VU因子関連抗原に陽性であり血管肉腫 と考えられた(図 3). 電顕像では, 腫瘍細胞は不整形 の核と顕著な核小体を有し, 細胞質内に赤血球を取り 込んでいた。 また, 細胞外には基底膜様構造を認めた。 一部の腫場細胞には Weibel-Palade body が認められ た(図 4 ).

術後経過：術後も肝機能は徐々に悪化したが,貧血, 凝固能異常は輸血, 血小板, FOY 投与により, 一時改 善傾向を示した. 血小板は $7.5 \times 10^{4} / \mathrm{mm}^{3}$ にまで改善し た.第14病日に肝動脈より動注化学療法 (5-FU 750mg, MMC 8mg）を施行し，第19病日にInterleukin-

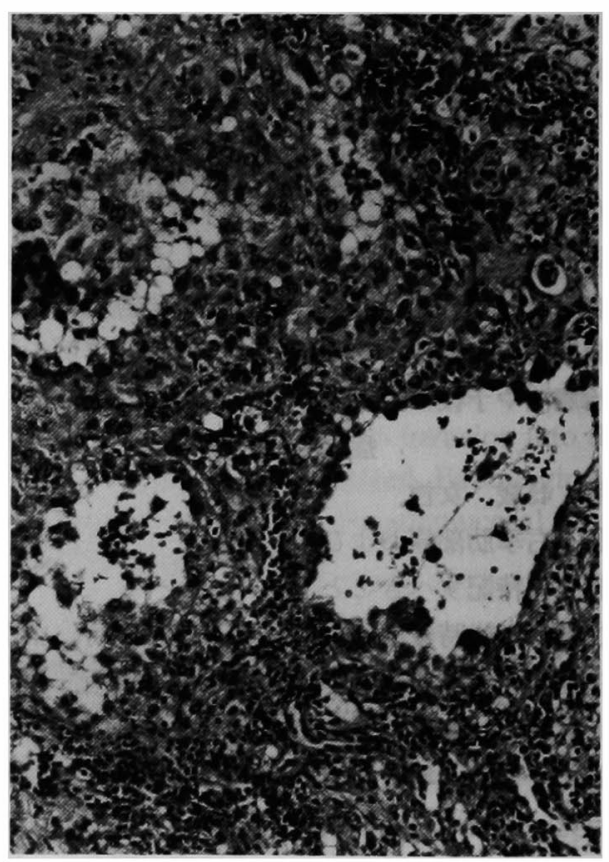

図 2 病理組織所見: N/C 比大で核小体の目立つ多 陵形の腫瘍細胞が，主として赤血球を貯留した大小 の血管腔様構造を形成して増殖し一部では充実性増 殖を示していた（HE染色, $\times 140)$. 


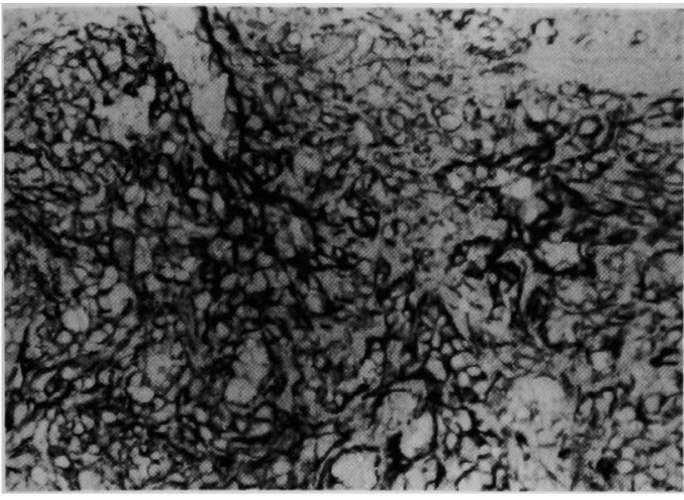

図3病理組織所見：免疫組織染色では腫瘍細胞は CD31に陽性であり血管肉腫と考えられた $(\times 256)$.

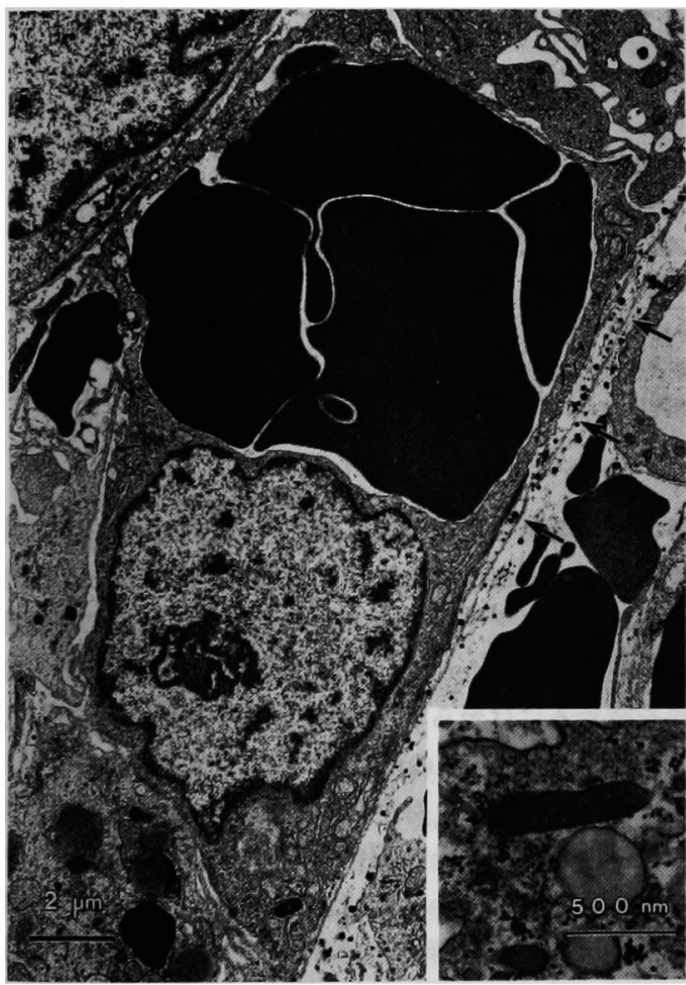

图 4 電子影微鏡所見：腫瘍細胞の核は不整形で核小 体は目立った．細胞質への赤血球の取り込み，およ び細胞外の基底膜様構造（ $\rightarrow$ ）を認めた。

2(teceleukin 35万単位)の全身投与を行った。しかし， 肝病変の急速な増覀により第21病日肝不全死した。

剖検所見：肝重量は $3,900 \mathrm{~g}$ て, 割面はスポンジ状を 呈した．肝蔵は腫瘍細胞で置き換わり，正常肝組織を ほとんど認めなかった，肝喏以外の他臟器に転移を認
めなかった。

以上の臨床所見と病理組織所見より，本症例は脾原 発血管肉腫と診断した。

\section{考察}

血管肉腫は，広義には，血管を構成する内皮細胞由 来の悪性血管内皮腫と周皮細胞由来の悪性血管周皮質

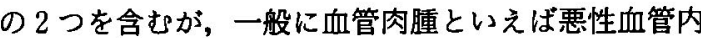
皮腫を指すことが多い2?.

脾原発の悪性腫湯は極めて稀であり, Bostick ${ }^{31}$ は約 8,000 例の手術と剖検例のうち 4 例のみが脾原発の悪 性腫場であったと報告している．また，血管肉腫のな かで原発巣が脾蔵のものは366例中16例（4\%）と報告 されている゙!。

血管肉腫症例において肝臓と脾葴に病巣を有する場 合，どちらが原発臟器かの判定に迷うことがある．原 発巣と転移巣の鑑別点として, (1)原発藏器には最大の

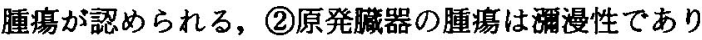
転移巣は結節性である，(3)肝原発例の脾転移例は極め て少なく脾原発例の肝転移は高頻度である，(4)肝原発 ではトロトラスト，塩化ビニルなどとの接触がしばし ばみられるが脾原発ではほとんどない，(5)肝原発では 小児例がかなりの数を占めるのに対して脾原発ではほ

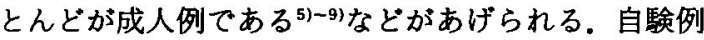
では, 脾臓に最大かつ潥漫性の病変を認め肝の病変は 多発結節性であり，上記薬物との接触歴を持たないこ とから脾原発の血管肉腫と考えられた。

脾原発血管肉腫の本邦報告例は，われわれが検索し えた限り21例のみであった（表 2)．男女比は10：11， 年齢は20歳から76歳（平均49歳）であった．主訴は腹 痛, 腹部膨満感, 腹部腫瘤, 負血などであり, いずれ も脾腫に基づく症状で，多くが著明な脾腫を伴ってい た。手術時または剖検時に転移の認められたものは21 例中17例 (81\%) で, 肝16例，骨 9 例，肺 7 例，腎 5 例, リンパ節 5 例, 膵 1 例であった. なお, Lazarus ら ${ }^{101}$ は33例中17例（52\%）に転移を認め（16例剖検時，1 例手術時), 肝11例，リンパ節 5 例，肺 4 例，膵 4 例， 骨 4 例と報告している。本邦報告21例中手術は12例 (57\%)に施行され，6例において手術時既に転移を認 めた. 1 例は周囲藏器への浸潤が高度であったため試 験切除に終わっている.これらのことは, 脾腫が進行 してから自覚症状が現れるために発見が遅れやすいこ と，また，腫瘍が非常に転移しやすいことを示してい る。また，脾破裂は21例中 2 例（10\%）に認められ， 脾破裂後に摘脾術が施行された，脾破裂は50例中 17 例 
表 2 脾原発血管肉腫の本邦報告例

\begin{tabular}{|c|c|c|c|c|c|c|}
\hline 報告者 & 年龄・性 & 主訴 & 摘脾術 & 脾重量 $(\mathrm{g})$ & 転移(手術時または剖検時开) & 予後” \\
\hline 滝 (1955) & 24 女 & 血尿 - 顔面浮腫 - 視覚障害 & - & 310 & 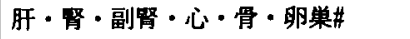 & 死（1日） \\
\hline 湯本 $(1960)$ & 32 男 & 腹部膨満感・左上腹部脰隆 & + & 1,700 & 無し & 生 ( 5 カ月) \\
\hline 北条(1967) & 76 男 & 䆩血 & - & 340 & 肝・肺・堅・骨・リンパ節\# & 死 ( 3 力月) \\
\hline 飯塚(1968) & 20 女 & 左胸痛 & + & $160^{*}$ & 不詳 & 死(12日) \\
\hline 山形(1973) & 69 男 & 左季肋部腫溜・るいそう & - & (試験切除) & 不詳 & 死 ( 1 力月) \\
\hline 冬広(1980) & 29 男 & 左季助部痛・脾腫 & + & 890 & 肝 & 生 ( 3 力月) \\
\hline 中澤 (1980) & 42 男 & 背部痛・腹部膨瀮感 & - & 250 & 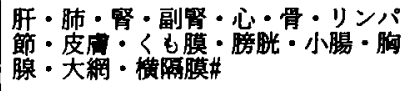 & 死 ( 2 力月) \\
\hline 小林(1982) & 28 男 & 左季肋部隀㨨 & + & 980 & 肺 & 不詳 \\
\hline 森内(1984) & 62 女 & 左胸部不快感・呼吸困難 & + & 950 & 肝 & 生 (5力月) \\
\hline 湯尾(1984) & 64 男 & 腹部隑満感 & - & 840 & 肝・肺・骨\# & 死 ( 3 力月) \\
\hline 長谷川(1985) & 28 女 & 䆩血・発熱・肝㯵大 & - & 510 & 肝・骨\# & 死 ( 5 力月) \\
\hline 政所(1986) & 34 男 & 上腹部鈍痛 & + & 175 & 無し & 生 (1 年 8 力月) \\
\hline 松井 (1987) & 49 女 & 左上腹部痛 & + & 1,382 & 抙 & 不詳 \\
\hline 林(1988) & 70 女 & 腹部嚚満感 & - & 190 & 旰・骨\# & 死 ( 4 力月) \\
\hline 澄川(1990) & 57 女 & 左上腹部腫䝷 & + & 1,450 & 脾門部リンパ笁 & 不詳 \\
\hline 西川 (1990) & 69 女 & 腰痛 & - & 655 & 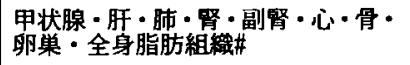 & 死 ( 4 力月) \\
\hline 增田 (1990) & 76 男 & 腹痛 & + & $50^{*}$ & 肝 $\cdot$ 肺\# & 死 ( 3 力月) \\
\hline 佐藤 (1991) & 50 男 & 賓血・全身倦莣感 & - & & 肝・胃\# & 死 ( 4 力月) \\
\hline 杉江 (1991) & 53 女 & 点出 & + & 不詳”・ & 肝・肺・堅・骨・リンパ節开 & 死 ( 3 年) \\
\hline 平崎(1994) & 41 女 & 全身倦忠感・食欲不振 & - & 220 & 肝・肺・骨・满頭部・リンパ節\# & 死(11日) \\
\hline 自験例(1994) & 45 女 & 右季肋部痛 ·右背部痛 & + & 1,540 & 肝\# & 死(21日) \\
\hline
\end{tabular}

・予後：手術例は術後の期間，非手術例は入院後の期間を示す。 *脾破裂後の摘腄症例

**摘脾術後の再発例の報告

（34\%）にも達するという報告6)もみられた。

本症例の免疫組織染色では腫瘍細胞は CD31および 第VU因子関連抗原に陽性であったがこれらの血管内皮 のマーカーは血管肉腫の診断には有用であると言われ ている(1).また,電顕像では一部の腫瘍細胞に WeibelPalade body が認められるなど血管肉腫に典型的な所 見)を認めた。

治療法は発見次第直ちに摘脾術を施行することが推 奖されている68812) 14). 自験例においては，肝缄にも病 変を認め, 術前に肝針生検を施行したが確定診断には 至らなかった，自験例の手術適応に関しては議論も あったが，(1)急速に增大する脾腫のため脾破裂の危険 性が考えられた, (2)血小板数 $1.2 \times 10^{4} / \mathrm{mm}^{3}$ と著明な血 小板減少を来たし出血傾向が出現した，(3)摘脾により 賀血と血小板減少が改善される可能性が考えられた， (4)組織学的に確定診断が得られる, (5)比較的良性な上 皮性血管内皮腫であれば術後に肝病変に対して ad. juvant therapy を施行することにより予後の改善も期 待し得る(5)ことから，手術を施行した。頭皮，骨盤部
等の他の部位の血管肉腫に対して, 化学療法, 放射線 療法, Interleukin-2の投与等が有効であったとの報告 も散見される ${ }^{16)-20)}$ 。自験例においては，術後に肝動注 化学療法, Interleukin-2の静脈内投与を施行するも奻 果を認めるには至らず,急速に肝不全に陥り死亡した。

脾原発血管肉腫の予後は極めて不良であり ${ }^{15)}$, Chen"1 は46例中 6 力月生存は 9 例 $(20 \%) て ゙ ， 5$ 年生存 は 1 例のみであったと報告している，本邦報告21例中 6 力月生存はわずか 2 例 (10\%) であり，1 例柱摘脾 術後 1 年 8 力月も再発を認めず ${ }^{13)}$, 他の 1 例は摘脾術 3 年後に多臟器転移にて死亡している ${ }^{211}$.

今後，本疾患に対する有効な治療法の確立が望まれ るとともに，脾腫の鑑別には本症も念頭に置き直ちに 摘脾術を施行することが重要であると思われた。

\section{結 語}

稀な脾原発性悪性血管内皮腫の 1 手術例を経験した ので，本邦報告21例を集計し若干の文献的考察を加え て報告した。 


\section{文献}

1）長谷川正和, 小泉 正, 関谷彰子他：脾原発悪性血 管内皮腫の 1 例. 臨放線 $41: 579-582,1996$

2）水無瀬昂, 野島孝之：血管肉腫. 病理と臨 10 ： 430-431, 1992

3) Bostick WL: Primary splenic neoplasms. Am J Path 21 : 1143-1165, 1945

4) Enzinger FM, Weiss SW: Malignant Vascular Tumors.: Soft Tissue Tumors. Mosby, St. Louis, 1988, p545-580

5) Gupta TD, Coombes B, Brasfield RD : Primary malignant neoplasms of the spleen. Surg Gynecol Obstet 120: 947-960, 1965

6) Autry JR, Weitzner S: Hemangiosarcoma of spleen with spontaneous rupture. Cancer 35 : 534-539, 1975

7) Silverman ML, Federman M, O'Hara CJ : Malignant hemangioendothelioma of the spleen. A case report with ultrastructural observations. Arch Pathol Lab Med 105: 300-304, 1981

8) Montemayor P, Caggiano V : Primary hemangiosarcoma of the spleen associated with leukocytosis and abnormal spleen scan. Int Surg 65 : $369-373,1980$

9) Chen KTK, Bolles JC, Gilbert EF : Angiosarcoma of the spleen. A report of two cases and review of the literature. Arch Pathol Lab Med 103: 122-124, 1979

10) Lazarus JA, Marks MS: Primary malignant tumors of the spleen. Am J Surg $71: 479-490$, 1946
11) Ohsawa M, Naka N, Tomita $Y$ : Use of immunohistochemical procedures in diagnosing angiosarcoma. Evaluation of 98 cases. Cancer $75: 2867-2874,1995$

12）平㠃照士, 都部和美, 岡咲博昭他: 脾原発血管肉腫 の 1 剖検例。癌の臨 $40: 211-216,1994$

13）政所節夫, 有馬純孝, 二見喜太郎他：脾原発血管肉 腫の 1 症例. 臨外 $44: 421-424,1989$

14）澄川 学, 小川東明, 今本 惊他：脾原発性血管肉 腫の 1 症例. 外科 $52: 643-646,1990$

15) Furui S, Itai $Y$, Ohtomo $K$, et al: Hepatic epithelioid hemangioendothelioma-Report of five cases. Radiology $171: 63-68,1989$

16）北島清彰, 紏川広己, 仲野 智他：骨盤部に発生し た Angiosarcomaに对する Ifosfamide 療法。西 日泌尿 48:1261-1265, 1986

17）藤岡 彰, 安井由美子, 馬場俊一他：抗癌剤の持続 動注療法が著効を呈した angiosarcoma $の 1$ 例. 日皮会誌 $96: 1025-1033,1986$

18）紫見 烈, 加藤司津子, 桑原まゆみ他：インターロ イキン 2 とペプロマイシンの併用療法によって一 時的に緩解状態を示した血管肉腫の1例. Biother $3: 170-174,1989$

19）織田知明, 佐伯光義, 山田秀和他：rIL-2 の全身投 与が有効であった悪性血管内皮細胞腫の 1 例. 皮 周 $31: 421-427,1989$

20）高久史桴：S.6820（遺伝子組換えヒトインターロ イキン 2)の臨床第 II相試験. Biother 3：796805,1989

21）杉江茂幸，西川秋佳，吉見直己 他：血管肉腫の 2 例. 日臨細胞会誌 $30: 564-570,1991$

\title{
PRIMARY SPLENIC ANGIOSARCOMA ASSOCIATED WITH SEVERE ANEMIA AND THROMBOCYTOPENIA - A CASE REPORT AND A REVIEW OF THE LITERATURE-
}

\author{
Masao YOSHITATSU, Kazuyasu NAKAO, Masaaki NAKAHARA, Nobuo OGINO, \\ Takeyoshi YUMIBA and Masahiko TSUJIMOTO \\ Departments of Surgery and Pathology*, Osaka Police Hospital
}

A 45-year-old woman was admitted to the hospital because of severe anemia and marked hepatosplenomegaly. Hematological examination showed severe anemia., thrombocytopenia and hepatic dysfunction. Abdominal computed tomography, ultrasonography and angiography demonstrated tumor-like multiple lesions in the liver and the spleen. Echo-guided needle biopsy of the liver suggested epithelioid hemangioendothelioma. Because of deterioration of anemia (RBC $90 \times 10^{4} / \mathrm{mm}^{3}$ ) and DICP (Platelet $1.2 \times 10^{4} / \mathrm{mm}^{3}$ ), a splenectomy was performed. Histological examination revealed angiosarcoma of the spleen associated with liver metastasis. The tumor cels showed positive staining for Factor VIIrelated antigen and CD31 immunohistologically. Postoperatively, the patient was treated with hepatic intraarterial chemotherapy (FAM) and systemic administration of interleukin-2. She died of hepatic failure due to increase of liver tumors. Primary splenic angiosarcoma is rare, and only 21 cases have been reported in the literature in Japan. Of these 21 cases, 12 cases underwent a splenectomy including only one survived case more than 6 months. this disease presents difficulty in early diagnosis and has a poor prognosis, and so it must be kept in mind as a probable differential diagnosis for splenic tumors. 